\title{
Effect of the Growth Period on Bioethanol Production from the Branches of Woody Crops Cultivated in Short-rotation Coppices ${ }^{1}$
}

\author{
Jong-Soo $\mathrm{Jo}^{2} \cdot$ Ji Young Jung ${ }^{3} \cdot$ Jae-Kyung Yang $\mathbb{C}^{3, \dagger}$
}

\begin{abstract}
Woody crops cultivated in short-rotation coppices are attractive sources of lignocellulosic materials for bioethanol production, since they are some of the most abundant renewable resources. In this study, we evaluated the effects of the growth period on bioethanol production using short-rotation woody crops (Populus nigra $\times$ Populus maxiwiczii, Populus euramericana, Populus alba $\times$ Populus glandulosa, and Salix alba). The carbohydrate contents of 3-year-old and 12-year-old short-rotation woody crop branches were $62.1-68.5 \%$ and $64.0-67.1 \%$, respectively. The chemical compositions of 3-year-old and 12-year-old short-rotation woody crop branches did not vary significantly depending upon the growth period. However, the 3-year-old short-rotation woody crop branches (glucose conversion: 26-40\%) were hydrolyzed more easily than their 12-year-old counterparts (glucose conversion: 19-24\%). Furthermore, following the fermentation of enzymatic hydrolysates from the crop branch samples (by Saccharomyces cerevisiae KCTC 7296) to ethanol, the ethanol concentration of short rotation coppice woody crops was found to be higher in the 3-year-old branch samples $(\sim 0.18 \mathrm{~g} / \mathrm{g}$ dry matter) than in the 12-year-old branch samples $(\sim 0.14 \mathrm{~g} / \mathrm{g}$ dry matter). These results suggest that immature wood (3-year-old branches) from short-rotation woody crops could be a promising feedstock for bioethanol production.
\end{abstract}

Keywords: short rotation coppice woody crops, growth period, glucose, bioethanol

\section{INTRODUCTION}

In the background of the global problems regarding the use of fossil fuels, searching for renewable and clean energy has become a key issue. Undoubtedly, ethanol fuel is an optimum energy alternative for fossil fuels. This has fostered the development of renewable energy sources that are suitable for long-term use (Zabed et al., 2017; Hahn-Hägerdal et al., 2006). In this context, new strategies promoting the use of biomass for the future supply of energy, chemicals, and other useful materials are being studied (Van Dam et al., 2004; Jørgensen et al., 2007).

Lignocellulosic biomass such as woody biomass is

\footnotetext{
1 Date Received March 18, 2019, Date Accepted May 13, 2019

2 Department of Interior Materials Engineering, Gyeongnam National University of Science and Technology, Jinju 52725, Republic of Korea

${ }^{3}$ Division of Environmental Forest Science and Institute of Agriculture \& Life Science, Gyeongsang National University, Jinju 52828, Republic of Korea

† Corresponding author: Jae-Kyung Yang (e-mail: jkyang@gnu.ac.kr, ORCID: 0000-0003-0423-6398)
} 
Effect of the Growth Period on Bioethanol Production from the Branches of Woody Crops Cultivated in Short-rotation Coppices

regarded as a promising energy source because it is renewable and abundant in carbohydrates (Jung et al., 2017; Jo et al., 2016). Lignocellulosic biomass serves as a cheap and abundant feedstock, which is required to produce fuel ethanol from renewable resources at reasonable costs. Extensive research regarding the conversion of lignocellulosic biomass to ethanol has been performed in the last two decades (Sindhu et al., 2016; Maurya et al., 2015; Wright, 1998; Bjerre et al., 1996; Duff and Murray, 1996; Reshamwala et al., 1995; Cadoche and Lopez, 1989; Um et al., 2016).

From a long-term perspective, woody crops cultivated in short-rotation coppices, such as poplars and members of the genus Salix, are considered possible alternatives to the current sources of lignocellulosic biomass. Poplars, which are the most widespread species across Europe, represent an important woody crop cultivated in short-rotation coppices as a source of lignocellulosic biomass. In Sweden, different species of Salix have been the main option with regards to the utilization of short-rotation forests for the production of bioenergy, i.e. for the production of heat and power. Over the years, more frost-tolerant and pest-resistant Salix varieties with considerably higher productivities have been developed through breeding, selection, and plantation management (Bawelin, 2002; Larsson, 1999; Tharakan et al., 2003). Instead of only producing heat and power by burning the Salix chips as they are, it has been proposed that the carbohydrate fraction (cellulose and hemicellulose) could be used for the production of fuel ethanol, and the solid residue, which consists mainly of lignin, could be used as a solid fuel. A dedicated woody biomass feedstock production system based on the short-rotation intensive culture (SRIC) of fast-growing willow clones is being developed for the northeastern and mid-western United States (Abrahamson et al., 1998). Populus species, along with species from its sister genus Salix, will provide valuable feedstock resources for advanced second- generation biofuels. Their inherent fast growth characteristics can particularly be exploited for managing short rotation, which is a time- and energy-saving alternative cultivation method for producing lignocellulosic feedstock (Porth and El-Kassaby, 2015).

The short-rotation coppice is a system to maximize the unit production of biomass by reducing the growth period of the crops. The most important short-rotation woody crops cultivated in the Republic of Korea are the hybrids Populus nigra $\times$ Populus maxiwiczii, Populus euramericana, Populus alba $\times$ Populus glandulosa, and Salix alba. Most of the biomass produced from these crops are used as pellets or chips, and only a limited amount of biomass is used as a source for producing bioethanol (Kim et al., 2011; Kim et al., 2015).

Therefore, in the present study, we evaluated the potential of branches from immature (3-year-old) and mature (12-year-old) short-rotation woody crops to serve as biomass resources for bioethanol production. We then analyzed the chemical compositions and compared the glucose conversion by performing the enzymatic hydrolysis of non-pretreated short-rotation woody crop branch samples. Finally, we investigated the effects of the growth period of the crops on the ethanol production by fermenting the converted enzymatic hydrolysates.

\section{MATERIALS and METHODS}

\subsection{Raw materials}

Woody crops cultivated in short-rotation coppices (Populus nigra $\times$ Populus maxiwiczii, Populus euramericana, Populus alba $\times$ Populus glandulosa and Salix alba) were collected from an experimental plot at the Korea Forest Research Institute in the city of Seoul, Republic of Korea (Fig. 1). Branches from 3-year-old and 12-year-old crops were debarked, chipped, 

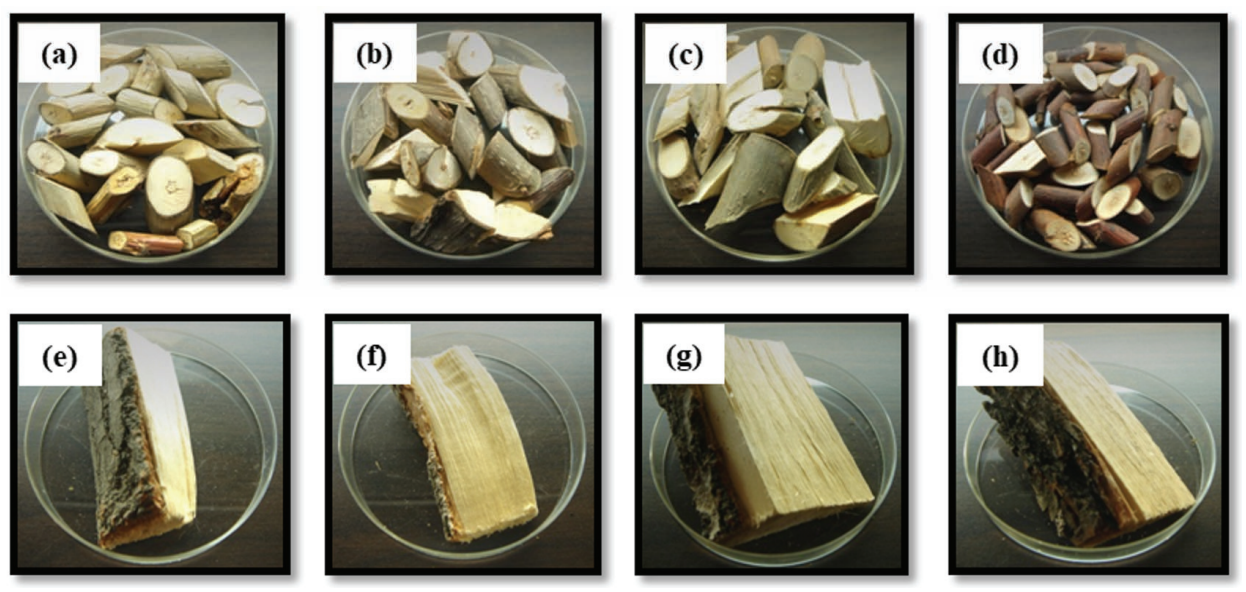

Fig. 1. Woody crops cultivated in short-rotation coppices. (a) 3-year-old P. nigra $\times$ P. maxiwiczii branch, (b) 3-year-old P. euramericana branch, (c) 3-year-old P. alba $\times$ P. glandulosa branch, (d) 3-year-old $S$. alba branch, (e) 12-year-old P. nigra $\times$ P. maxiwiczii branch, (f) 12-year-old $P$. euramericana branch, (g) 12-year-old $P$. alba $\times$ P. glandulosa branch, (h) 12-year-old S. alba branch.

and ground with a Wiley mill, and the fraction between 20-mesh screen and 80-mesh screen was collected for further use. This material was then stored at room temperature.

\subsection{Analysis of the chemical composition}

The raw material composition was determined according to the analytical methods for biomass described by the National Renewable Energy Laboratory (NREL, Golden, CO). The extractive content was determined based on the solubilized material obtained after a Soxhlet extraction with ethanol for $24 \mathrm{~h}$. The ash content was determined according to the method involving the calcination of raw materials at $550^{\circ} \mathrm{C}$. The cellulose and hemicellulose contents were determined based on the monomer content measured after a two-step acid hydrolysis procedure to fractionate the fiber. The first step was performed by treating the samples with $72 \% \mathrm{H}_{2} \mathrm{SO}_{4}$ at $30^{\circ} \mathrm{C}$ for $60 \mathrm{~min}$. In the second step, the reaction mixture was diluted until the $\mathrm{H}_{2} \mathrm{SO}_{4}$ concentration reached $4 \%$, and then autoclaved at $121^{\circ} \mathrm{C}$ for $1 \mathrm{~h}$. This hydrolysate was then analyzed for sugar content by high-performance liquid chromatography (HPLC) using a Waters 2695 liquid chromatography system with a refractive index detector. An Aminex HPX-87P carbohydrate analysis column (Bio-Rad, Hercules, CA) operating at $85^{\circ} \mathrm{C}$ with deionized water as the mobile-phase $(0.6 \mathrm{~mL} / \mathrm{min})$ was used. The solid residue remaining after this acid hydrolysis process was considered the acid-insoluble lignin portion. The acid-soluble lignin in the hydrolysates was also quantified. The acid-soluble lignin content was determined based on UV spectrophotometric measurements at $205 \mathrm{~nm}$.

\subsection{Enzymatic hydrolysis}

The enzymes used for the enzymatic hydrolysis were Celluclast $1.5^{\circledR}$ L (Novo Co., Denmark), which is cellulase prepared by a culture solution of Trichoderma reesei, and Viscozyme ${ }^{\circledR}$ L (Novo Co., Denmark), a $\beta$-glucosidase. One gram of biomass was transferred to a 250-mL Erlenmeyer flask, followed by the addition of $50 \mathrm{~mL}$ of $0.1 \mathrm{M}$ citrate buffer ( $\mathrm{pH} 4.8$ ). Next, appropriate amounts of cellulase (65 FPU/g) and $\beta$ 
Effect of the Growth Period on Bioethanol Production from the Branches of Woody Crops Cultivated in Short-rotation Coppices

-glucosidase (24 CBU/g) were added. The flask was placed in a shaking incubator (IS-97IR from Jeio-Tech Co., Korea) at $50^{\circ} \mathrm{C}$ and $150 \mathrm{rpm}$ and incubated for 96 h. Samples were withdrawn after 0, 12, 24, 48, 72, and $96 \mathrm{~h}$ to monitor the progress of hydrolysis. Each sample taken from the hydrolysis solution was heated to $100^{\circ} \mathrm{C}$ immediately for $10 \mathrm{~min}$ to denature the enzymes, cooled to room temperature, and then centrifuged for $15 \mathrm{~min}$ at 3,000 rpm (Hanilmicro-12 from Hanil Science Industrial Co., Korea). The supernatant was used for glucose analysis using an HPLC system (Shimadzu, Kyoto, Japan) with a refractive-index detector (Shimadzu), and the sample containing glucose was utilized for yeast fermentation.

The percent glucose conversion was calculated as follows (Eq. (1)):

$$
\text { Glucose conversion }(\%)=\frac{\mathrm{GH}}{\mathrm{GP}} \times 100 \cdots \cdots \cdots(1)
$$

where GH is the dry-weight percentage of glucose in enzyme hydrolysis supernatant (g glucose/g solids hydrolyzed), and GP is the dry-weight percentage of glucose in the raw material (g glucose/g the raw material).

\subsection{Fermentation}

Fermentation of the liquids was performed using the ordinary yeast strain Saccharomyces cerevisiae KCTC 7296, which ferments glucose and mannose, but not xylose or other pentoses. The inoculum was prepared by transferring the organisms cultured on GPYA medium (glucose, $40 \mathrm{~g} \cdot \mathrm{L}^{-1}$ peptone, $5 \mathrm{~g} \cdot \mathrm{L}^{-1}$ yeast extract, $5 \mathrm{~g} \cdot \mathrm{L}^{-1}$ agar, $15 \mathrm{~g} \cdot \mathrm{L}^{-1}$ ) into a $100-\mathrm{mL}$ flask. The culturing was carried out at $35^{\circ} \mathrm{Con}$ an orbital shaker for $24 \mathrm{~h}$. The inoculum concentration was about $1.5 \times 10^{8}$ yeast cells/mL. The $\mathrm{pH}$ was adjusted to 5.5 with $20 \%$ (w/w) $\mathrm{Ca}(\mathrm{OH})_{2}$. The fermentation was performed in $100-\mathrm{mL}$ glass flasks with a working volume of $20 \mathrm{~mL}$; the fermentation solution consisted of $18.5 \mathrm{~mL}$ of filtrate, $0.5 \mathrm{~mL}$ of nutrients, and $1 \mathrm{~mL}$ of inoculum (an aqueous suspension of yeast). Yeast was used at a concentration of $1.5 \times 10^{8}$ yeast cells $/ \mathrm{mL}$, while the final concentrations of the nutrients were $0.5 \mathrm{~g} \cdot \mathrm{L}^{-1}\left(\mathrm{NH}_{4}\right)_{2} \mathrm{HPO}_{4}$, $0.025 \mathrm{~g} \cdot \mathrm{L}^{-1} \mathrm{MgSO}_{4} \cdot 7 \mathrm{H}_{2} \mathrm{O}, 0.1 \mathrm{M} \mathrm{NaH}_{2} \mathrm{PO}_{4}$, and $1 \mathrm{~g} \cdot \mathrm{L}^{-1}$ yeast extract (Taherzadeh et al., 1996). The flasks were sealed with rubber stoppers through which hypodermic needles had been inserted for the removal of the $\mathrm{CO}_{2}$ produced, as well as for the withdrawal of samples. The concentration of fermentable sugars was adjusted by the addition of glucose to a total concentration of $5 \mathrm{~g} \cdot \mathrm{L}^{-1}$ to avoid the influence of the variation in sugar concentration between different filtrates. A reference solution was prepared with $5 \mathrm{~g} \cdot \mathrm{L}^{-1}$ glucose to serve as a control fermentation sample. The flasks were incubated at $35^{\circ} \mathrm{C}$ for $96 \mathrm{~h}$, and the withdrawn samples were analyzed for sugars and ethanol. Samples were withdrawn after $0,12,24,48,72$, and $96 \mathrm{~h}$ to monitor the progress of the fermentation process.

\subsection{Analysis of sugar and ethanol content}

The content of monomeric sugars in the enzymatic hydrolysates (glucose) was analyzed using an HPLC system (Shimadzu, Kyoto, Japan) with a refractiveindex detector (Shimadzu). The separation of the sugars was performed using an Aminex HPX-87P column (Bio-Rad, Hercules, CA, USA) at $85^{\circ} \mathrm{C}$, with water as the eluent, and at a flow rate of $0.6 \mathrm{~mL} / \mathrm{min}$.

Additionally, the ethanol contents of the fermentation samples were analyzed using an Aminex HPX-87 $\mathrm{H}$ column (Bio-Rad) at $65^{\circ} \mathrm{C}$, with $5 \mathrm{mM} \mathrm{H}_{2} \mathrm{SO}_{4}$ as the eluent, and ata flow rate of $0.6 \mathrm{~mL} / \mathrm{min}$ (Sluiter and Hames, 2004).

All samples were filtered through a $0.2 \mu \mathrm{m}$ filter before analysis to remove particulate matter. All analytical determinations were performed in duplicate and the average results are shown. 


\subsection{Statistical analysis}

Statistical analysis was carried out using the SAS statistical software. ANOVA was used for the statistical analyses, and Duncan's multiple comparison range test ( $\mathrm{p} \leq 0.05$ ) was used to determine significant differences between the means.

\section{RESULTS and DISCUSSION}

\subsection{Effect of the growth period on the chemical composition of woody crops cultivated in short-rotation coppices}

Woody crops have high contents of cellulose and hemicellulose, which can be readily hydrolyzed into fermentable sugars (Binod et al., 2010). Cellulose (as glucose) can either be broken down hydrolytically or enzymatically (by cellulases) into glucose. Glucose, galactose, and mannose, which are six-carbon sugars (hexoses), are readily fermented to ethanol by many naturally occurring organisms, but the pentoses xylose and arabinose (containing only five carbon atoms) are fermented to ethanol only by a few native strains, and usually at relatively low yields (Mosier et al., 2005).

Table 1 summarizes the chemical composition of 3-year-old and 12-year-old P. nigra $\times$ P. maxiwiczii, P. euramericana, $P$. alba $\times P$. glandulosa, and $S$. alba branches. The cellulose portion of the 3-year-old $P$. nigra $\times$ P. maxiwiczii, $P$. euramericana, $P$. alba $\times P$. glandulosa, and S. alba branches comprised $44.2 \%$,

Table 1. Chemical compositions of 3-year-old and 12-year-old woody crop branches ${ }^{\mathrm{a}}$

\begin{tabular}{|c|c|c|c|c|}
\hline Composition & $\begin{array}{l}\text { P. nigra } \times \\
P . \text { maxiwiczii } \\
\end{array}$ & P. euramericana & $\begin{array}{l}P . \text { alba } \times \\
P . \text { glandulosa, } \\
\end{array}$ & S. alba \\
\hline \multicolumn{5}{|c|}{ 3-year-old woody crop branches } \\
\hline Extractive & $8.7 \pm 0.2$ & $6.5 \pm 0.1$ & $8.6 \pm 0.1$ & $9.6 \pm 0.4$ \\
\hline Cellulose as glucose & $44.2 \pm 0.6$ & $46.0 \pm 0.8$ & $48.6 \pm 0.8$ & $44.1 \pm 0.5$ \\
\hline Hemicellulose as & 18.1 & 18.9 & 19.9 & 18.0 \\
\hline Xylose & $14.1 \pm 0.5$ & $14.7 \pm 0.2$ & $15.5 \pm 0.4$ & $14.0 \pm 0.4$ \\
\hline Galactose & $1.0 \pm 0.4$ & $2.1 \pm 0.2$ & $2.2 \pm 0.1$ & $2.0 \pm 0.2$ \\
\hline Arabinose & $2.0 \pm 0.1$ & $1.0 \pm 0.1$ & $1.1 \pm 0.1$ & $1.0 \pm 0.1$ \\
\hline Mannose & $1.0 \pm 0.1$ & $1.1 \pm 0.2$ & $1.1 \pm 0.1$ & $1.0 \pm 0.2$ \\
\hline Acid insoluble lignin & $25.7 \pm 0.8$ & $25.9 \pm 0.7$ & $20.6 \pm 0.8$ & $25.2 \pm 0.4$ \\
\hline Acid soluble lignin & $1.1 \pm 0.2$ & $0.6 \pm 0.1$ & $0.8 \pm 0.4$ & $0.9 \pm 0.1$ \\
\hline Ash & $1.1 \pm 0.1$ & $2.0 \pm 0.3$ & $1.1 \pm 0.1$ & $1.4 \pm 0.1$ \\
\hline \multicolumn{5}{|c|}{ 12-year-old woody crop branches } \\
\hline Extractive & $7.0 \pm 0.6$ & $6.2 \pm 0.5$ & $5.8 \pm 0.5$ & $4.6 \pm 0.2$ \\
\hline Cellulose as glucose & $46.9 \pm 0.5$ & $47.3 \pm 0.9$ & $47.3 \pm 0.8$ & $45.4 \pm 0.6$ \\
\hline Hemicellulose as & 20.2 & 19.5 & 19.5 & 18.6 \\
\hline Xylose & $15.9 \pm 0.4$ & $15.1 \pm 0.4$ & $15.1 \pm 0.7$ & $14.5 \pm 0.4$ \\
\hline Galactose & $2.1 \pm 0.3$ & $1.1 \pm 0.3$ & $1.1 \pm 0.5$ & $2.1 \pm 0.4$ \\
\hline Arabinose & $1.1 \pm 0.1$ & $2.2 \pm 0.1$ & $2.2 \pm 0.2$ & $1.0 \pm 0.4$ \\
\hline Mannose & $1.1 \pm 0.2$ & $1.1 \pm 0.1$ & $1.1 \pm 0.2$ & $1.0 \pm 0.1$ \\
\hline Acid insoluble lignin & $23.0 \pm 0.7$ & $22.7 \pm 0.5$ & $22.2 \pm 0.5$ & $26.0 \pm 0.6$ \\
\hline Acid soluble lignin & $1.2 \pm 0.4$ & $0.9 \pm 0.3$ & $1.3 \pm 0.3$ & $1.8 \pm 0.4$ \\
\hline Ash & $1.2 \pm 0.2$ & $1.7 \pm 0.1$ & $1.2 \pm 0.1$ & $1.5 \pm 0.1$ \\
\hline
\end{tabular}

${ }^{\text {a }}$ Data in the table are based on oven-dried samples. 
Effect of the Growth Period on Bioethanol Production from the Branches of Woody Crops Cultivated in Short-rotation Coppices

$46.0 \%$, $48.6 \%$, and $44.1 \%$ glucose, respectively. These branches also comprised 18.1\%, 18.9\%, 19.9\% and $18.0 \%$ of hemicellulosic sugars as the main sugar, and xylose (14.0-15.5\%), galactose (1.0-2.2\%), arabinose (1.0-2.0\%), and mannose (1.0-1.1\%) were the other additional available carbohydrates (data not shown). The lignin content from these branches $(P$. nigra $\times$ P. maxiwiczii, $P$. euramericana, $P$. alba $\times P$. glandulosa, and S. alba) ranged from 21.4-26.8\%, the extractive content ranged from 6.5-9.6\%, and the ash content ranged from $1.1-2.0 \%$.

In the 12-year-old $P$. nigra $\times P$. maxiwiczii, $P$. euramericana, $P$. alba $\times P$. glandulosa, and S. alba branches, the cellulose content ranged from 45.4$47.3 \%$, the hemicellulose content ranged from 18.6$20.2 \%$, the lignin content ranged from $23.5-27.8 \%$, the extractive content ranged from 4.6 to $7.0 \%$, and the ash content ranged from $1.2-1.7 \%$.

The carbohydrate content (cellulose and hemicellulose) of woody crops cultivated in short-rotation coppices has been reported to be higher than that in case of other woody plants and agricultural residues (Jorgensen et al., 2007; Zhu and Pan, 2010). We expected that longer harvest ages will produce increased contents of carbohydrate and lignin. However, the carbohydrate and lignin contents of the 3-year-old and 12-year-old woody crop branches showed no significant difference. Therefore, the immature wood samples, i.e. branches from woody crops grown in short-rotation coppices for a short period may be promising options as sources of feedstock for bioethanol production, especially in terms of their abundant availability and low costs.

\subsection{Effects of the growth periods on glucose conversion in woody crops cultivated in short-rotation coppices}

Enzymatic hydrolysis of the non-pretreated raw materials from the 3-year-old and 12-year-old woody crop branches was carried out. The glucose conversion of the 3-year-old and 12-year-old woody crop branch samples has been presented in Fig. 2. The glucose conversion in the 3-year-old $P$. nigra $\times P$. maxiwiczii,

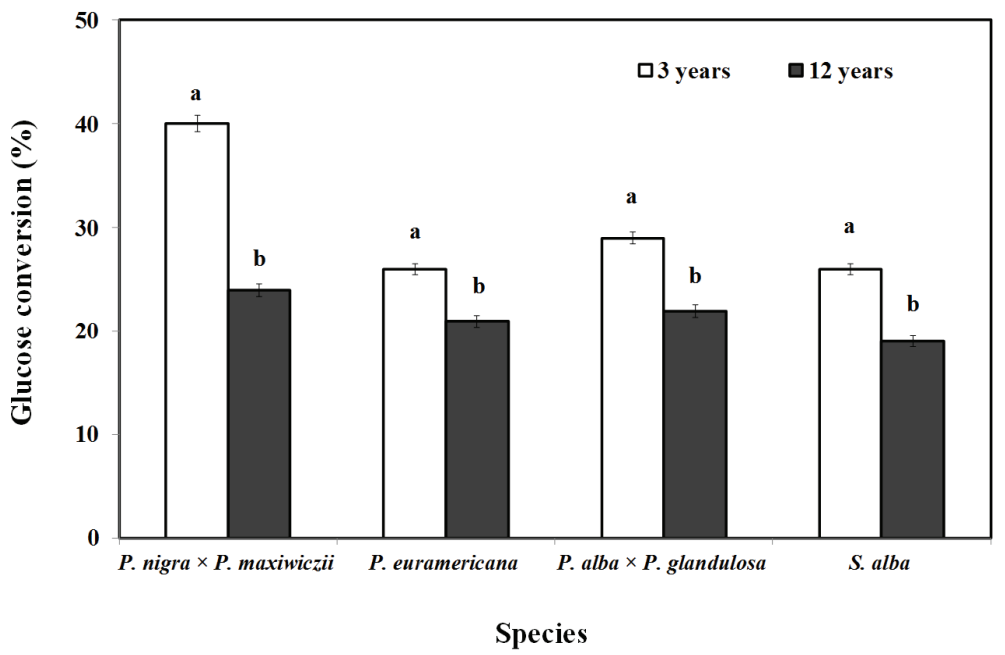

Fig. 2. Effects of crop growth periods on glucose conversion in 3-year-old and 12-year-old P. nigra $\times$ $P$. maxiwiczii, $P$. euramericana, $P$. alba $\times P$. glandulosa, and $S$. alba branches. Enzymatic hydrolysis conditions: Cellulase (65 FPU/g), $\beta$-glucosidase (24 CBU/g), pH 4.8, 50 ${ }^{\circ} \mathrm{C}, 150 \mathrm{rpm}, 96$ hours. The data are expressed as the mean $\pm \mathrm{SD}(n=3)$. 
P. euramericana, $P$. alba $\times P$. glandulosa, and S. alba branches was $40 \%, 26 \%, 29 \%$, and $26 \%$, respectively; the glucose conversion in the 12-year-old $P$. nigra $\times$ P. maxiwiczii, P. euramericana, P. alba $\times$ P. glandulosa, and S. alba branches was $24 \%, 21 \%, 22 \%$, and $19 \%$, respectively. The maximum glucose conversion was attained in case of the 3-year-old $P$. nigra $\times P$. maxiwiczii branches (40\%), and the lowest glucose conversion, in case of the 12-year-old $S$. alba branches. Thus, it was seen that the glucose conversion in the 3-year old woody crop branch samples (26-40\%) was higher than that in the 12-year-old woody crop branch samples (1924\%). Significant difference between the chemical compositions of the 3-year-old and 12-year-old woody crop branch samples was not observed (Table 1), but different results were obtained with regards to glucose conversion.

We estimate that this difference is because of physical characteristics such as crystallinity, hardness, or specific gravity due to growth periods. Wood lignification creates a physical barrier for enzymatic attack on the polysaccharides during the growth periods. Therefore, only those organisms that possess enzymes capable of destroying the lignin or at least altering its protective association with the polysaccharides, are capable of decaying wood. The structure of cellulose, which comprises crystalline and amorphous regions, also restricts the action of depolymerizing enzymes. Initially, these enzymes can only affect the non-crystalline portions (Quartey, 2009).

\subsection{Effects of the growth period on ethanol production from woody crops cultivated in short-rotation coppices}

Batch fermentation was carried out with media comprising hydrolysates of the branches from woody crops cultivated in short-rotation coppices (P. nigra $\times$ P. maxiwiczii, P. euramericana, $P$. alba $\times$ P. glandulosa,
S. alba) to investigate the time profiles of sugar consumption and ethanol formation. The time courses of the fermentation processes are shown in Fig. $3-$ Fig. 6.

The sugar consumption and ethanol production from P. nigra $\times$ P. maxiwiczii branches is shown in Fig. 3 . The time course of ethanol production showed a similar pattern for the hydrolysates of both the 3-year-old and 12-year-old $P$. nigra $\times P$. maxiwiczii branch samples (Fig. 3a and Fig. 3b). At the time point (48 h) when the maximum concentration of ethanol was attained, the ethanol conversion rate was over $90 \%$. The ethanol concentrations obtained from the fermentation of the 3-year-old and 12-year-old woody crop branch hydrolysates were $0.17 \mathrm{~g} / \mathrm{g}$ dry matter and $0.14 \mathrm{~g} / \mathrm{g}$ dry matter, respectively.

As shown in Fig. 4a and Fig. 4b, the ethanol concentrations of the hydrolysates of both the 3-year-old and 12-year-old $P$. euramericana branch samples increased significantly with the increase in sugar consumption. The ethanol conversion rate was over $93 \%$, and the maximum ethanol concentration (0.14 g/g dry matter) was obtained in case of the hydrolysates of the 3-year-old woody crop branches.

The sugar consumption and ethanol production in the $P$. alba $\times P$. glandulosa branch samples is shown in Fig. 5. The ethanol conversion in case of the substrates derived from the 3-year-old or 12-year-old P. alba $\times$ P. glandulosa branch samples (Fig. 5a and Fig. 5b) was similar, reaching $96.6 \%$ and $96.0 \%$, respectively. Furthermore, the maximum ethanol concentration (0.14 g/g dry matter) was obtained after incubating the hydrolysates of the 3-year-old woody crop branch samples for $48 \mathrm{~h}$.

The time course of sugar consumption and ethanol production using the enzymatic hydrolysates from the 3-year-old and 12-year-old S. alba branches is shown in Fig. 6a and Fig. 6b. The highest concentration of ethanol reached $0.18 \mathrm{~g} / \mathrm{g}$ dry matter and $0.10 \mathrm{~g} / \mathrm{g}$ dry 
Effect of the Growth Period on Bioethanol Production from the Branches of Woody Crops Cultivated in Short-rotation Coppices
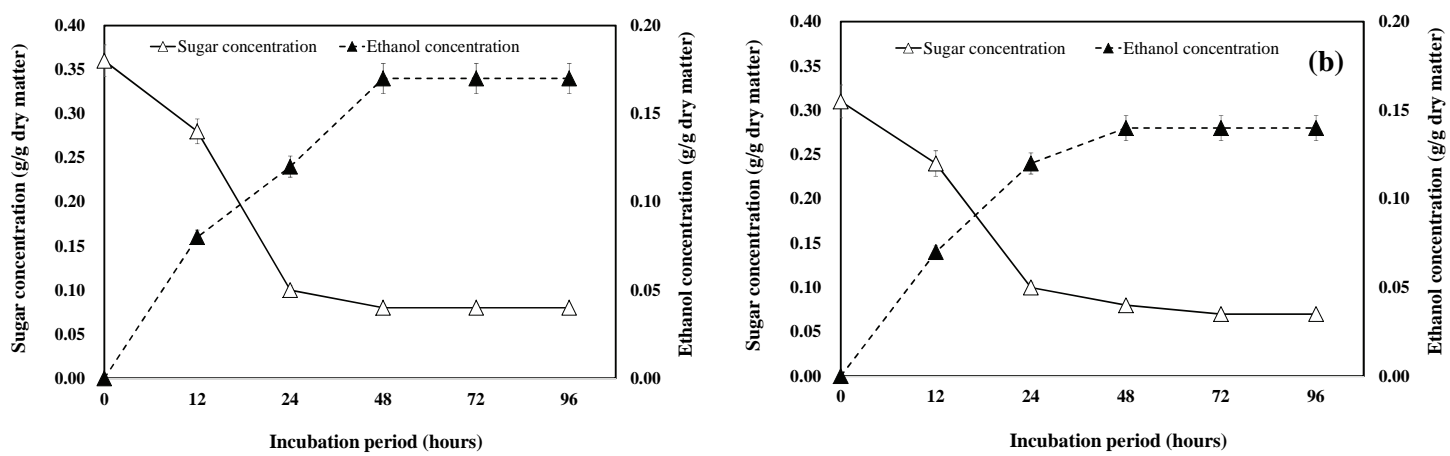

Fig. 3. Fermentation kinetics during ethanol production from $P$. nigra $\times$ P. maxiwiczii branches by $S$. cerevisiae KCTC 7296 using batch fermentation. (a) 3-year-old $P$. nigra $\times P$. maxiwiczii branches, (b) 12-year-old $P$. nigra $\times$ $P$. maxiwiczii branches. The data are expressed as the mean $\pm \mathrm{SD}(n=3)$.
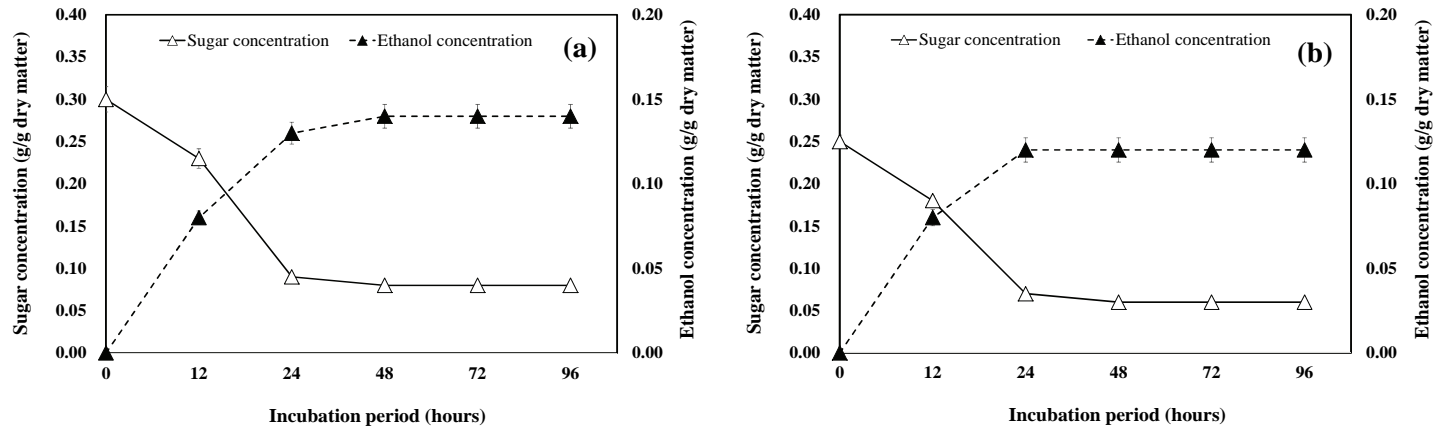

Fig. 4. Fermentation kinetics during ethanol production from P. euramericana by S. cerevisiae KCTC 7296 using batch fermentation. (a) 3-year-old P. euramericana branches, (b) 12-year-old P. euramericana branches. The data are expressed as the mean \pm SD $(n=3)$.
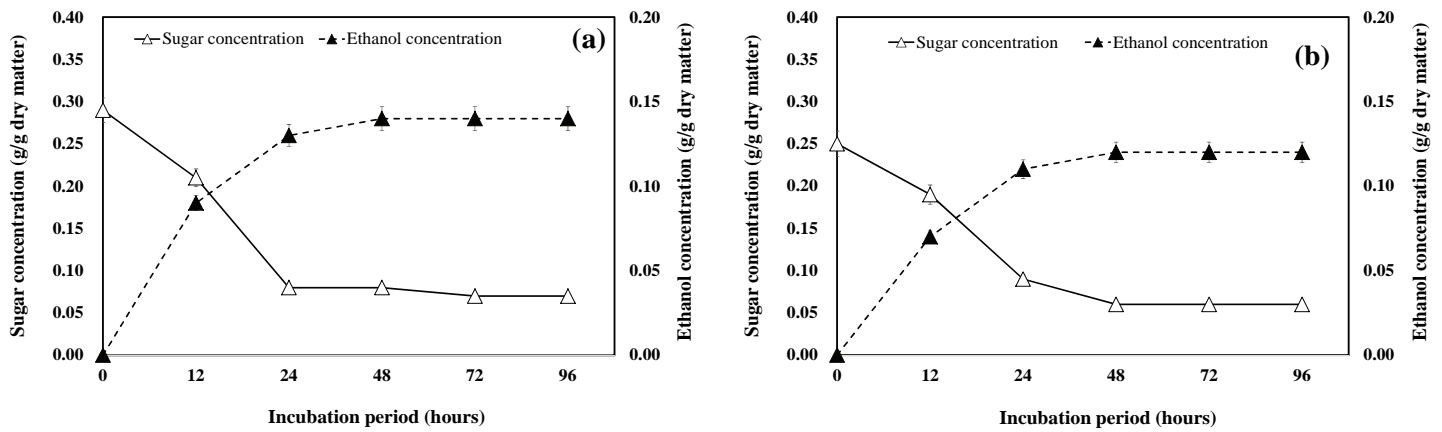

Fig. 5. Fermentation kinetics during ethanol production from $P$. alba $\times$ P. glandulosa by $S$. cerevisiae KCTC 7296 using batch fermentation. (a) 3-year-old P. alba $\times$ P. glandulosa branches, (b) 12-year-old P. alba $\times$ $P$. glandulosa branches. The data are expressed as the mean $\pm \mathrm{SD}(n=3)$. 

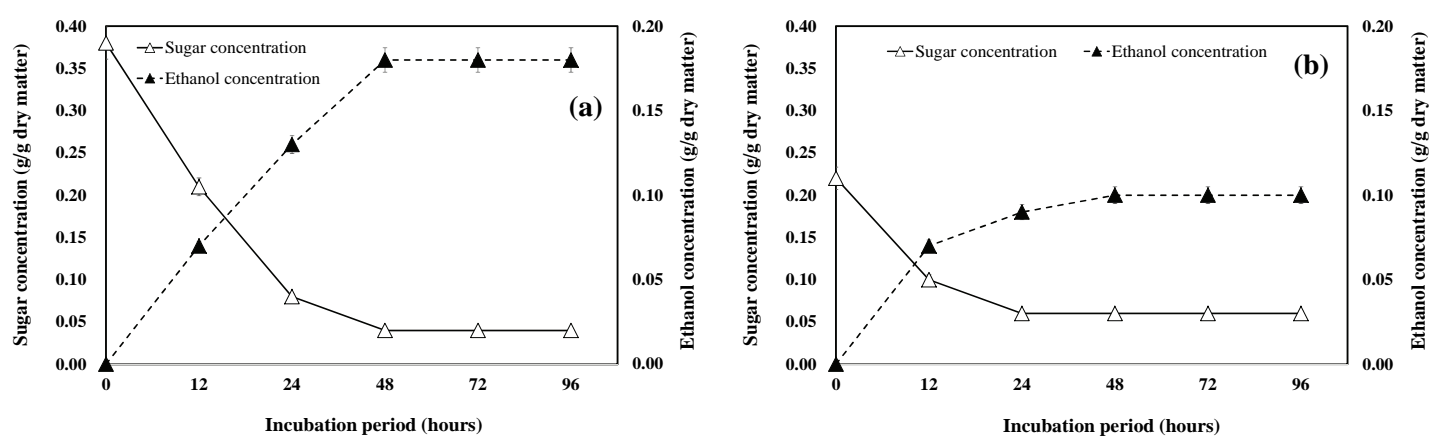

Fig. 6. Fermentation kinetics during ethanol production from $S$. alba by S. cerevisiae KCTC 7296 using batch fermentation. (a) 3-year-old S. alba branches, (b) 12-year-old S. alba branches. The data are expressed as the mean $\pm \mathrm{SD}(n=3)$.

matter after $48 \mathrm{~h}$ of fermentation in case of the 3-year-old and 12-year-old $S$. alba branches, respectively.

The correlation between ethanol production and reducing sugar content was high; the ethanol production inversely correlated with sugar consumption. Further, the sugar concentration decreased during the fermentation, coinciding with an increase in ethanol production. The sugar concentration fell rapidly and consistently during the first $24 \mathrm{~h}$ of fermentation, after which it decreased slowly. When the enzymatic hydrolysates of the short-rotation woody crops were fermented, the ethanol conversion rate was over $90 \%$, and as expected, the ethanol concentration was higher after the fermentation of the 3-year-old woody crop branch sample hydrolysates, than after the fermentation of the 12-year-old woody crop branch sample hydrolysates.

\section{CONCLUSION}

We investigated the potential of branches from immature (3-year-old) and mature (12-year-old) short-rotation woody crops (Populus nigra $\times$ Populus maxiwiczii, Populus euramericana, Populus alba $\times$ Populus glandulosa, and Salix alba) to serve as feedstock for bioethanol production. This study showed that there was no significant difference between the cellulose, hemicellulose, and lignin contents of the branches from 3-year-old and 12-year-old woody crops cultivated in short-rotation coppices. However, after the enzymatic hydrolysis, the glucose conversion was found to be higher in the branches from the 3-year-old short-rotation woody crops (glucose conversion: 2640\%)) than in branches from their 12-year-old counterparts (glucose conversion: 19-24\%). Likewise, after fermentation, the ethanol concentration was found to be higher in the branches from the 3-year-old short-rotation woody crops ( $0.18 \mathrm{~g} / \mathrm{g}$ dry matter) ) than in branches from their 12-year-old counterparts ( $0.14 \mathrm{~g} / \mathrm{g}$ dry matter).

Our results showed that the immature (3-year-old) wood samples (from crops grown for short periods) can be used as a biomass source for producing bioethanol. We recommend that further studies on aspects such as the biomass contents produced per unit area and after the removal of bark from the branches be carried out.

\section{ACKNOWLEDGMENT}

This work was supported by Gyeongnam National University of Science and Technology Grant in 2018 2020. 
Effect of the Growth Period on Bioethanol Production from the Branches of Woody Crops Cultivated in Short-rotation Coppices

\section{REFERENCES}

Abrahamson, L.P., Robison, D.J., Volk, T.A., White, E.H., Neuhauser, E.F., Benjamin, W.H., Peterson, J.M. 1998. Sustainability and environmental issues associated with willow bioenergy development in New York (USA). Biomass and Bioenergy 15(1): 17-22.

Bawelin, F. 2001. Willow-fast growing weed or a profitable alternative to cereals?. Sveriges Utsadesforenings Tidskrift 111(2): 69-72.

Binod, P., Sindhu, R., Singhania, R.R., Vikram, S., Devi, L., Nagalakshmi, S., Kurien, N., Sukumaran, R.K., Pandey, A. 2010. Bioethanol production from rice straw: An overview. Bioresource Technology 101(13): 4767-4774.

Bjerre, A.B., Olesen, A.B., Fernqvist, T. 1996. Pretreatment of wheat straw using combined wet oxidation and alkaline hydrolysis resulting in convertible cellulose and hemicellulose. Biotechnology and Bioengineering 49(5): 568-577.

Cadoche, L., Lopez, G.D. 1989. Assessment of size reduction as a preliminary step in the production of ethanol from lignocellulosic wastes. Biological Wastes 30(2): 153-157.

Duff, S.J.B., Murray, W.D. 1996. Bioconversion of forest products industry waste cellulosics to fuel ethanol: A review. Bioresource Technology 55(1): 1-33.

Hahn-Hägerdal, B., Galbe, M., Gorwa-Grauslund, M.F., Lidén, G., Zacchi, G. 2006. Bio-ethanol- the fuel of tomorrow from the residues of today. Trends in Biotechnology 24(12): 549-556.

Iyer, P.V., Lee, Y.Y. 1999. Product inhibition in simultaneous saccharification and fermentation of cellulose into lactic acid. Biotechnology Letters 21(5): 371-373.

Jo, J.S., Jung, J.Y., Byun, J.H., Lim, B.K., Yang, J.K. 2016. Preparation of cellulose acetate produced from lignocellulosic biomass. Journal of the Korean Wood Science and Technology 44(2): 241-252. Jung, J.Y., Ha, S.Y., Park, J.H., Yang, J.K. 2017. Optimization of alkali pretreatment from steam exploded barley husk to enhance glucose fraction using response surface methodology. Journal of the Korean Wood Science and Technology 45(2): 182-194.

Jørgensen, H., Kristensen, J.B., Felby, C. 2007. Enzymatic conversion of lignocelluloses into fermentable sugars: challenges and opportunities. Biofuels, Bioproducts and Biorefining 1(2): 119134.

Kim, H.Y., Lee, J.W., Jeffries, T., Choi, I.G. 2011. Evaluation of oxalic acid pretreatment condition using response surface method for producing bio-ethanol from yellow poplar (Liriodendron tulipifera) by Simultaneous Saccharification and Fermentation. Journal of the Korean Wood Science and Technology 39 (1): 75-85.

Kim, H.Y., Hong, C.Y., Kim, S.H., Yeo, H. M., Choi, I. G. 2015. Optimization of the organosolv pretreatment of yellow poplar for bioethanol production by response surface methodology. Journal of the Korean Wood Science and Technology 43(5): 600-612.

Kumar, S., Singh, S.P., Mishra, I.M., Adhikari, D.K. 2009. Recent Advances in Production of Bioethanol from Lignocellulosic Biomass. Chemical Engineering technology 32(4): 517-526.

Maurya, D.P., Singla, A., Negi, S. 2015. An overview of key pretreatment processes for biological conversion of lignocellulosic biomass to bioethanol. 3 Biotech 5(5): 597-609.

Mosier, N., Wyman, C., Dale, B., Elander, R., Lee, Y. Y., Holtzapple, M., Ladisch, M. 2005. Features of promising technologies for pretreatment of lignocellulosic biomass. Bioresource Technology 96(6): 673-686. 
Porth, I., El-Kassaby, Y. A. 2015. Using Populus as a lignocellulosic feedstock for bioethanol. Biotechnology Journal 10(4): 510-524.

Quartey, G.A. 2009. Relationships between some anatomical, physical and durability properties of the wood of some lesser utilised Ghanaian hardwoods. Thesis submitted to the Department of Wood Science and Technology at the Kwame Nkrumah University of Science and Technology, in partial fulfilment of the requirement for the degree of Doctor of Philosophy, pp. 150.

Reshamwala, S., Shawky, B.T., Dale, B.E. 1995. Ethanol production from enzymatic hydrolysates of AFEX-treated coastal Bermuda grass and swichgrass. Applied Biochemistry and Biotechnology 51(52): 43-55.

Sindhu, R., Binod, P., Pandey, A. 2016. Biological pretreatment of lignocellulosic biomass - An overview. Bioresource Technology 199: 76-82.

Sluiter, A., Hames, B., Ruiz, R., Scarlata, C., Sluiter, J., Templeton, D. In: NREL laboratory analytical procedures: determination of structural carbohydrates and lignin in biomass. Golden, CO: NREL; 2004 Available at / http: // www1. eere. energy. gov / biomass /analytical_procedures. htmlS.

Taherzadeh, M.J., Liden, G., Gustafsson, L., Niklasson, C. 1996. The effects of pantothenate deficiency and acetate addition on anaerobic catch fermentation of glucose by Saccharomyces cerevisiae. Applied Microbiology and Biotechnology 46(2): 176-182.

Tharakan, P.J., Volk, T.A., Abrahamson, L.P., White, E.H. 2003. Energy feedstock characteristics of willow and hybrid poplar clones at harvest age. Biomass Bioenergy 25: 571-580.

Um, M., Shin, G.J., Lee, J.W. 2016. Enhancement of ethanol production by the removal of fermentation inhibitors, and effect of lignin-derived inhibitors on fermentation. Journal of the Korean Wood Science and Technology 44(3): 389-397.

Van Dam, J., Faaij, A.P.C., Hilbert, J., Petruzzi, H., Turkenburg, W.C. 2004. Large-scale bioenergy production from soybeans and switchgrass in Argentina: part B. Environmental and socioeconomic impacts on a regional level. Renew Sustainable Energy Review 13(8): 1679-1709.

Wright, J.D. 1998. Ethanol from biomass by enzymatic hydrolysis. Chemical Engineering Progress 84(8): 62-74.

Zabed, H., Sahu, J.N., Suely, A., Boyce, A.N., Faruq, G. 2017. Bioethanol production from renewable sources: Current perspectives and technological progress. Renewable and Sustainable Energy Reviews 71: 475-501. 